\title{
Prohibition of Reformation in Peius and the Principle of Constitutionality
}

\author{
Csongor Herke ${ }^{1} \&$ Csenge D. Tóth ${ }^{2}$ \\ ${ }^{1}$ Associate Professor, Head of Department at Department of Criminal Procedure Law and Forensic Science, \\ Faculty of Political and Legal Sciences, University of Pécs, Pécs, Hungary \\ ${ }^{2} \mathrm{PhD}$ candidate at Department of Criminal Procedure Law and Forensic Science, Faculty of Political and Legal \\ Sciences, University of Pécs, Pécs, Hungary \\ Correspondence: Csenge D. Tóth, Department of Criminal Procedure Law and Forensic Science, Faculty of \\ Political and Legal Sciences, University of Pécs, Pécs, Hungary, Address: 48-as tér 1., Pécs, 7622. Tel: \\ 36-7250-1599/ 23185. E-mail: toth.csenge@ajk.pte.hu
}

Received: February 15, 2012 Accepted: March 7, 2012 Online Published: May 11, 2012

doi:10.5539/jpl.v5n2p49 URL: http://dx.doi.org/10.5539/jpl.v5n2p49

The research is financed by (Sponsoring information): Faculty of Legal and Political Sciences, University of Pécs

\begin{abstract}
The requirement of the prohibition of reformatio in peius may arise taking into consideration several basic principles of the criminal procedure. The most important element of the prohibition of reformatio in peius is that it is a legal guarantee for the defence to be able to file an appeal without the risk that a judgment might be altered to the detriment of the accused. Therefore, the accused will have confidence that the appeal will not do wrong to his interest.

Nevertheless, the prohibition of reformatio in peius can only be considered as a legal favour, but at the same time, many problems and counterarguments are being discussed regarding the prohibition of reformatio in peius, such as the violation of fundamental principles and constitutionality. This paper examines the reasons for the existence of the prohibition of reformatio in peius in the course of the criminal procedure while arguing its connection to the principle of constitutionality.
\end{abstract}

Keywords: reformation in peius, ne bis in idem, nullum crimen sine lege, nulla poena sine lege, constitutionality, fundamental principles

\section{Introduction}

It is worth considering that we think about the prohibition of reformatio in peius as a direct interpretation of constitutional law. TIEDMANN (1991) regards as a tendency that principles of criminal law are derived directly or indirectly from the Constitution more and more often. One of the advantages thereof is that principles which are mentioned by the Constitution cannot be simply crossed since to be able to that the Constitution of Hungary needs to be altered which action requires the majority of $2 / 3$ in the Parliament. Therefore, the abolishment of certain principles is practically excluded (meaning for example that death penalty cannot be reintroduced by the Criminal Code even if the right to life was removed from the Constitution of Hungary; or theft cannot be legalized by violating the right to property as described in the Constitution of Hungary). However, not every principle of criminal procedure requires special constitutional basis at the same time because this would lead to the inflationary use of the Constitution, hence the undervaluation thereof. If we take into consideration the prohibition of reformatio in peius, the prevailing opinion says that prohibition of reformatio in peius belongs to these simple principles which do not require constitutional grounding.

\section{Principle of Equality}

Going by FLAD (1989), we examine the principle of equality concerning the relationship between prohibition of reformatio in peius and the Constitution. First of we should compare the situation of a defendant who filed for remedy and as a result he is being sentenced to a more severe punishment to a defendant who leaves the 
judgment to became effective and as a result he do not get a heavier sentence. According to FLAD (1989), in the first case (when heavier sentence is imposed) the principle of equality is violated (Article XIV of the Hungarian Constitution of April 25 of 2011) since the reason for actual discrimination is the act of filing for a remedy and as a result thereof different procedural situation occurred despite the fact that the circumstances of each case were entirely identical (crime, level of guilt, level of proof etc.).

At the same time, in legal literature it is generally recognized that no claim can be resulted from the principle of equality in order to administrate injustice in a uniform manner. That is, if the appellate court meat out more severe punishment according to the facts of the case and new means of evidence it must be assumed that the decision in this judgment is right and the former sentence (imposed by the judgment of first instance) was wrong about the amount of punishment.

\section{Prohibition of Double Jeopardy}

FLAD (1989) connects prohibition of reformatio in peius to the principle of ne bis in idem. He raises the issue that the judgment of first instance concluded the procedure of first instance on behalf of the state, therefore, any further punitive demand ceases to exist, if prosecution did not apply for remedy to the detriment of the defendant (this theory can be correlated to the doctrine of loss of rights which was written above). This would mean that the heavier punishment of the appellate court basically constitutes another punishment (at least concerning the difference between the two punishments).

Nevertheless, we cannot accept this train of thought in this form, since if the judgment of first instance is appealed it is still a uniform procedure, moreover, in such case res iudicata does not set in.

According to GRÜNWALD (1979), prohibition of reformatio in peius does not concern the prohibition of double jeopardy because it is related only to a procedure concluded by a final judgment.

\section{Principle of Constitutionality}

Let it be distinctly understood that prohibition of reformatio in peius breaks through the principle of substantial justice. This contradicts the principle that substantial justice prevails in criminal procedure law while in civil procedure formal justice rules. If the prohibition of reformatio in peius in criminal matters has connective force then its dogmatic basis needs to be explained.

FLAD (1989) regards the prohibition of reformatio in peius as a consequence of the principle of constitutionality but he does not argue this statement in detail. At the same time, the argument that prohibition of reformatio in peius by itself derives from principle of constitutionality cannot be unanimously accepted since e.g. in Great Britain and Switzerland this institution does not exist but, according to LAUCKNER (1913), still there is no doubt about the constitutionality of these countries.

So, arguments about the prohibition of reformatio in peius being the direct consequence of constitutionality cannot be accepted. Countries went through different historical development and this is what influences different legal systems. By right of this, we can assume at best that if most of the states established a principle protecting the defendant then this would mean that this is an element of a state founded on the rule of law.

But it is a fact: states not grounded on the rule of law (mainly dictatorships) rejected the prohibition of reformatio in peius or limited it as they could.

Principle of constitutionality, according to the prevailing opinion, is an independent principle of administration of justice and which is expressly established by section 1 of Article $C$ of the Constitution of Hungary of April 25, 2011 (and which is recorded expressis verbis in the introduction of Act LXVI of 1997 on organization and management of courts). Although, BLECKMANN (1993) regards this as an element of objective constitutional law, there is a possibility to go back to special fundamental rights in case of violation of general liberty of action, and by this, the violation of a constitutional principle can directly be enforced. It is considerably hard to evaluate the importance of this constitutional principle since it is necessary to make the actual obligations and prohibitions concrete, to be more precise, in a manner that the basic elements of constitutionality and legal security must remain protected.

According to the prevailing opinion, this principle - in contradiction with the point of view of STERN (1984) among others - constitutes not only an idea of formal state founded on the rule of law, where the law and order serves as a control of exercising the power of the state but it embodies the endeavour to reach substantial justice as well (so called substantial constitutional concept). However, the realization of these two elements is especially difficult, and conceals the danger that law enforcement institutions modify the principle of substantial constitutionality according to their subjective ideas about justice. 
According to ROXIN (1998), criminal procedure law is "the seismograph of a constitution" which provides an inflexible legal order and actually represents two functions. On the one hand, justness appears as an important component of the principle of constitutionality because "a state can be founded on the rule of law only if it is certain that criminals are prosecuted, sentenced and legitimately punished by existing laws". On the other hand, the requirement of a fair trial belongs with a constitutional criminal procedure. This manifests itself especially in the equality of procedural arms of prosecution and defence since people are not only the subject of the criminal procedure but essential components thereof due to their procedural rights. Thus, both of these principles shall be taken into consideration, if we would like to make a conclusive decision whether the prohibition of reformatio in peius is an element of the principle of constitutionality.

It can be considered as an opposition to binding this prohibition to the principle of constitutionality that some critics regard the prohibition of reformatio in peius as a possibility to break through substantial justice, if the appellate court establishes that the original sentence was too inconsiderable (but it could not been changed due to the prohibition of reformatio in peius). The ground of this criticism is that substantial justice exists, which can be determined in court, however, this is argued by a number of scientists - e.g. BALOGH, FINKEY, ANGYAL. Relativity appears concerning the expression of substantial justice, in the same way we can subjectively experience guilt or injustice. The reason for this is that the expression cannot be comprehended experientially. This can be seen, according to BAUMANN (1999), when we think about the fact that different countries punish the same crime by different penalties.

In order to render this expression more manageable a fictitious consensus needs to be reached with respect to its semantic content. Still, it is impossible to actually survey the numerous aspects of this complex concept; the concerned court shall reach this fictitious consensus regarding its meaning. The problem of relativity cannot be solved definitely based on such subjectivity, justifiable outcomes may emerge which requires either a certain scope for action in order to decide a question regarding the inconsistency between the penalty and substantial justice; or substantial justice is not a solid starting point but a concept having certain inner scope of action (limited objectivity of the concept of substantial justice).

Another problem lies in the fact that the court can establish guilt and its extent only subjectively, and by doing this it is bound by limited human perception (limited ascertainabilty of substantial justice). This, according to the prevailing opinion, can be placed on the account of theory of scope-of-action when imposing a punishment, meaning that when recognizing the impossibility of the concept a certain scope of action is created within the frame of penalty. Within this scope of action every penalty should be considered suitable for the guilt. According to TRÖNDLE (1997), penalty does not have an exact amount. Of course there are numerous cases when a fictitious objective observer can modify the statement of facts, evaluation of evidence or legal evaluation so the prohibition of reformatio in peius may lead to the breakthrough of the substantial justice, however, this is not typical and by a similar method the existence of many other legal institutions could be questioned.

Thus, the court has a certain scope of action regarding the estimation of the amount of culpability and punishment which, however, does not mean the breakthrough of substantial justice. For example, if the court of first instance sentenced two years imprisonment and the appellate court tends to sentence three years imprisonment but it is forbidden by the prohibition of reformatio in peius, it sustains the two years imprisonment and this cannot be regarded as breakthrough of substantial justice. This is not even changed by the fact that even if the prosecutor had filed an appeal the defendant would have been sentenced to three years imprisonment. If we concede that the prohibition of reformatio in peius is an obstacle to substantial justice then the same would apply to section 371 (2) of the Criminal Procedure Code too since the law forbids the court of second instance the minor amendment of the punishment in case of identical statement of facts even if the punishment of first instance does not meet substantial justice. However, if we think about it a little more, numerous other legal institution (legal force, partial legal force, retrial, judicial review bounded by the deadline to the detriment of the defendant) obstruct the success of substantial justice but these are not regarded contradictory to constitutional criminal procedure, indeed, these are basic legal institution of effective constitutional criminal procedure. Therefore, the prohibition of reformatio in peius promotes the effectiveness of justice within a certain scope of action, realizing a part of substantial justice thereby. Consequently, we cannot say that the prohibition of reformatio in peius contradicts constitutionality, especially considering that question of guilt was judged by a court.

The prohibition of reformatio in peius, as a part of a fair procedure, can be considered as a requirement of the principle of constitutionality. An important point of view, according to BLECKMANN (1993), is that the prohibition of reformatio in peius is a principle guarding general trust since we traced it back to the requirement of legal security. This is revealed for example by the fact that the protection of trust is an important element of 
fair procedure. The guarantee of such protection of trust is that the defendant had faith that procedure will continue somehow. That is, the defendant may believe that the punishment of first instance is to low because of the prosecutor's appeal to the detriment of the defendant. The trust can be deduced from the fact that the defendant could proceed on the premise that the court has satisfied the punitive demand of the state by delivering a judgment, if the prosecutor did not file an appeal to the detriment of the defendant. In a normal case, the punitive demand of state is satisfied only if both of these requirement are fulfilled (the prosecutor's acknowledgement in addition to the court's sentence), in such case the defendant may believe with good reason that the punitive demand will not be claimed any more (at least not to his detriment). This belief can become stronger in as much as it corresponds with the statement of facts established by the court. The defendant usually does not have to reckon with the unfairness of the legal evaluation of first instance, and he is under a threat of a more serious punishment during the remedy process (namely, the identical statement of facts would result in a heavier sentence). Nevertheless, if the prosecutor files an appeal in favour of the defendant the prosecutor indicates to the defendant that the punitive demand of the state is not as high as it was established by the court of first instance.

Another problem might emerge because the defendant must file the appeal before the aforesaid trust exists, since the trust can become real only after the lapse of the deadline for filing an appeal by the prosecutor because the defendant cannot know beforehand that the prosecutor considers the punitive demand satisfied or not, if the acknowledgment is not expressed when delivering the judgment. DEGENHART (1996) thinks that this trust need protection as well. This would be missing, if the defendant should set out from the conflict with substantial justice at any time. If new evidence come up, the evaluation of evidence of first instance was entirely wrong or the interpretation of the law was entirely inaccurate and due to this a lot heavier sentence should be imposed then we could say that the prohibition of reformatio in peius breaks through the principle of substantial justice, thus, the trust would not deserve to be protected. For example, if the court of first instance found the defendant guilty of deadly bodily harm but the evidence suggests that it was committed premeditated (concerning both the crime and its consequences) then the trust cannot be protected which is linked to the conclusion of a graver classified case of homicide and by this means the omission of major aggravation of punishment. However, if the original sentence is within such a scope of action which is regarded by the appellate court as belonging to the proper legal evaluation of the statement of facts (evaluation of evidence, classification of crime etc.), then we cannot talk about inconsistency according to the above mentioned argument.

It can be laid down as a fact that the prohibition of reformatio in peius, as set forth by law, is not a compulsory requirement of the principle of trust, and thus, neither of the principle of constitutionality. It rather breaks through substantial justice in many cases. Nevertheless, there is a certain scope of action where different punishments are suited to the level of guiltiness, and they comply with substantial justice. For this reason, it can be found that the prohibition of reformatio in peius lies in the idea of the protection of trust. With this, the prohibition of reformatio in peius is partly an element of principle of constitutionality and partly a simple right.

According to the present prevailing opinion, the prohibition of reformatio in peius is only the equitable decision of the legislator. This opinion find the reason in the fact that the defendant should not be influenced by the fear of getting a detrimental consequence due to the remedy procedure when he decides on the question whether to exercise his right to legal remedy. According to BLOY (1986), the prohibition of reformatio in peius is a legal benefit guaranteed to the defendant. This opinion is followed by many authors engaged in criminal law concerning juveniles. We wonder whether this psychological dilemma can explain the prohibition of reformatio in peius entirely. The deadline for appeal is the same concerning both the defendant and the prosecutor, so the defendant, who considers filing an appeal, shall take into consideration that the prosecutor might also file an appeal, especially if he had asked for a three day time to think, and in such case it is possible that the prohibition of reformatio in peius did not set in - but it is also possible that it does. How does the question on prohibition of reformatio in peius influence the defendant when deciding on filing the appeal?

We should examine the element of trust in order to interpret the prohibition of reformatio in peius from the point of view of criminal politics. On the one hand, the defendant should not have significant disadvantage because of filing the appeal. If no appeal was filed to the detriment of the defendant then - if he would not have had filed an appeal either - no graver punishment would threaten him. On the other hand, defendants tend to have trust that punishment of first instance satisfies the punitive demand of the state, if the court has examined the case and prosecution acknowledged the judgment. This kind of trust does not always deserve protection (as we mentioned before). The trust does not even deserve to be protected, if substantial justice meets striking conflicts, especially if totally new points of view come up only during remedy procedures. Even thought, this is recognized by the legislator concerning the prohibition of reformatio in peius in the same way like concerning the similar cases of 
legal force. Otherwise, the prohibition of reformatio in peius could not be regarded as a general legal term, if it should be referred to in each case differently because this would be inconsistent with the prohibition of legal security.

It is verifiable that the prohibition of reformatio in peius is based on the principle of constitutionality in the slightest degree, and it is not obligatory but a very important element of the criminal procedure. From the point of view of criminal politics, the legal ground of this institution lies in equity and protection of trust.

With regard to the constitutional procedure, this key concept was highlighted basically by German legal literature. They defined the concept of constitutionality as

a) separation of legislator, executive and jurisdictional powers,

b) state are bound by statutes and law,

c) citizens' fundamental rights restricts the power of the state,

d) in cases of infringement of right people can turn to independent courts.

According to MEYER-GROSSNER (1985), generally speaking, the prohibition of reformatio in peius is a legal benefit given to the defendant by the legislator. The prohibition of reformatio in peius does not result inevitably from the principle of constitutionality. The legislator has a sovereign right to determine in what degree can (or must) the prohibition apply. The purpose of the prohibition of reformatio in peius is to prevent that no fear will influence the defence's decision on whether to file an appeal or not. The prevailing opinion does not connect the prohibition of reformatio in peius to the principle of constitutionality, although after world war II new theories emerged which said that there is a close connection between the prohibition and the principle of constitutionality. If the defendant should fear at the moment of giving statements about an appeal after the judgment of first instance has been delivered and this would prevent the filing of an appeal, then, according to MÜLLER (1947), this would endanger constitutional justness.

Even if no demand arose in legal literature to abolish the prohibition of reformatio in peius, this would not answer the question whether the prohibition of reformatio in peius is constitutional, thus, could it be derived from the Constitution, and still this question can have a conspicuous importance regarding the prohibition of reformatio in peius. To think about the prohibition of reformatio in peius can bear numerous contradictions within, therefore it is more accurate to consider the prohibition as a constitutional guarantee.

\section{The Principle of ne bis in idem}

The principle of ne bis in idem is not included expressis verbis in the Constitution, but the Commentary of the Constitution said that section 2 (1) of the Constitution of 1949 (article B (1) of the Fundamental Law of 2012; "Hungary is an independent democratic state founded on the rule of law") contains the principle of ne bis in idem. This provision is the clause on the state founded on the rule of law of the Constitution. The Constitutional Court passed three decisions in 1992 which defined the principle and latter content of constitutionality at the bottom. In these decisions the Constitutional Court pointed out that principles of nullum crimen sine lege and nulla poena sine lege are constitutional principles the content of which is determined by numerous penal rules. Such rule is the definition of a criminal offence and legal definitions of punishment and penal system as described in the Criminal Code. Both the definition of crime and punishment are crucial in terms of criminal culpability and calling to account of an individual.

The constitutional freedom and human rights of the individual are not only affected not only by special part and amount of punishment of criminal law but by the closed system of rules of sentencing and punishability. Every change in the rules of criminal punishability concerns basically and directly personal freedom and constitutional situation of the individual. According to the Constitution, the constitutionality of criminal rules should not be measured only by the criminal guarantees expressed by the Constitution. Several other basic principles and fundamental right apply to criminal law. Therefore, there is no separate prohibitive rule in the Constitution regarding objective criminal liability, but it can be derived from the right to human dignity that only a liable person should be punished constitutionally.

Another constitutional principle, which is an element of a state founded on the rule of law, is also that the burdens and conditions of the punitive claim of the state, as determined by law, cannot be changed to the detriment of a person whose act is being tried in a criminal process. Neither the change of criminal politics nor the negligence or fault of the proceeding authorities can be contributed to the disadvantage of the offender. Owing to this can the unlawfulness of retroactive statute, which result in a heavier judgment in any way, be established. So, if the statute of limitation is effective then the offender gains an unconditional right to not to be 
punished. This right comes to existence due to the cessation of the punitive claim of the state, if the time set forth to exercise punitive power of the state, prosecuting and sentencing the offender has passed. The trust in law absolutely requires that if one of the causes for terminating punishability stands then another act should not render the same crime punishable.

In the same way as presumption of innocence does not protect only the innocent, the statute of limitation terminates punishability irrespectively of why the offender was not indicted; the negligence of the state cannot be counted to the detriment of the defendant. In such extent, presumption of innocence is similar to the prohibition of reformatio in peius since in both cases the negligence of the authorities pursuing crime results in the non-effectiveness (in a certain extent) of the principle of legality.

These conclusions of the Constitutional Court describe the requirement of content of constitutional criminal law, according to the Commentary. The limited punitive power of the state is established by the guarantees of constitutional criminal law. The principles of nullum crimen sine lege, nulla poena sine lege, the consequential prohibition of retroactive criminal legislation, ne bis in idem, presumption of innocence, right to legal remedy are all elements of the definition of constitutional criminal law, independently from how they are put into words by the Constitution, or from are they even in the Constitution expressis verbis or not. This independency is created by section 2 (1) of the Constitution, so the basic institutions of constitutional criminal law can be handled on the same level, on the level of the Constitution. The Constitutional Court outlined the formal requirements derived from the constitutionality of criminal law in parallel with the requirements of content (Note 1).

Double jeopardy is declared by item 1 . of Article 4 of the Protocol No.7 to the Convention for the Protection of Human Rights and Fundamental Freedoms (signed at Rome on 4 November 1950) which says:

"No one shall be liable to be tried or punished again in criminal proceedings under the jurisdiction of the same State for an offence for which he has already been finally acquitted or convicted in accordance with the law and penal procedure of that State.”

This Convention and its Protocols were promulgated by Act XXXI of 1993 in Hungary, so its dispositions are binding. Therefore, even if the Constitution does not have provisions about the principle of ne bis in idem expressis verbis, there is a legal provision which expressly records the prohibition of double jeopardy.

Several detailed provision of the Criminal Procedure Code elaborate the essence of this principle since section 6 (3) d) says that no criminal proceedings may be initiated, and criminal proceedings in progress shall be terminated or a verdict of acquittal be rendered, if a final court verdict has already been delivered on the action of the defendant (with the exception of extraordinary legal remedies and special procedures).

The wording of the law expressly forbids to impose a punishment repeatedly for the same act. According to SCHROEDER (1997), based on a more detailed surveillance, this norm constitutes a triple prohibition:

- it forbids to impose a new sentence after the incorrectness of the punishment of first instance and the turning to account the content of culpability (this is based on principles of guilt and justice and according to VON MÜNCH (1992), it is inevitable);

- the principle of ne bis in idem forbids to impose a new sentence even if it turns out that the final judgment is incorrect and it did not exhausted the standards of guilt (in such case, principles of guilt and justice would argue in favour of the new sentence, but after a final judgment on acquittal - even if it is unlawful - no new procedure should be allowed due to the requirement of legal legal safety which is ahead of substantial justice);

- $\quad$ at last, it is a principle of one-time action of the law enforcement authorities, whereupon repeated decisions cannot be passed in one case, the court is prevented from passing a judgment on the question of guilt. From the point of view of dogmatics, this prohibition is not less than a procedural obstacle which shall be taken into account ex oficio. Thus, not only new sentencing but initiating criminal procedure repeatedly as well is forbidden in compliance with regulations.

The prohibition shows impact against a formally final judgment. The principle of ne bis in idem appears in the relationship between legal security and substantial justice, basically, between the protection of each person's freedom and punitive claim of the state. After a final judgment, section 6 of the Criminal Procedure Code determines the requirement of legal security.

This means that the principle of substantial justice, that the offender should be sentenced to a penalty which is adequate to the act and guilt, is broken through partly by the principle of ne bis in idem. Res iudicata is a procedural principle but according to SCHMINDT-ASSMANN (1990), at the same time it is definition deriving from the existence of a state founded on the state of law, as a fundamental principle of justice. 
It stand to reason that it cannot be regarded as repeated sentencing, if the defendant is sentenced to a heavier penalty during the next stage of remedy procedure for any reason, if an appeal was filed to his detriment. The burden of the prohibition is the legal force. Until this has not set in, the aggravation of penalty violate the rule of law. The aim of substantial justice can be realized by this means, if an appeal is filed to the detriment of the accused by the prosecutor (usually public prosecutor).

That is a whole different situation when only the defendant has exercised his right to file for remedy and the prohibition of reformatio in peius sets in. The dogmatical ground for the prohibition of reformatio in peius does not lie in the concept of legal force, but rather in the concept of legal benefit. When the law enforcement authority (prosecutor) does not appeal against the defendant, the punitive claim of the state shall be considered as enforced and as a lost right (satisfied). Aggravation resulted from the defendant's appeal would mean a contradictory behaviour of the state. That is precisely why the prohibition exists, since the state has revoked its right to further (heavier) punitive measures when the prosecutor did not file an appeal against the judgment of first instance.

Such silent consent - to the waiver of a claim of heavier punishment - of the prosecutor results in the possibility that further criminal procedures may only benefit the defendant, meaning that the former judgment may be upheld or the penalty therein will be reduced (or by any chance an order on acquittal or termination of procedures will replace the original sentence). At the same time, we can talk about the prohibition of res judicata (double jeopardy) of a modified content because nobody should be punished twice for the same act according to general criminal laws.

In the same way as the principle of on-time law enforcement has crossed the principle of substantial justice in order to guarantee legal security, the prohibition of reformatio in peius - as defined by criminal procedure law crosses the same principle too. In both cases the state exercised only a part of its punitive demand and it cannot be extended (satisfied). If it is discovered that the punishment of first instance does not suit the gravity of crime and level of guilt then aggravating the punishment may only be possible after the formal legal force set in during an extraordinary legal remedy procedure -, if the conditions therefore are met. Consequently, the prohibition of reformatio in peius is an element of constitutionality and breaks through the requirement for substantial justice because the question on prevalence between legal security and substantial justice is answered by legal force with favouring legal security. Apart from the fact that the prohibition of reformatio in peius burdens the principle of substantial justice it should not be considered as conflicting the principle of constitutionality. That is, substantial justice can be overturned by the positive and constitutionally well founded argument, as explained before. The principle of ne bis in idem means, in connection with the prohibition of reformatio in peius, that nobody may be sentenced disadvantageously regarding the means and extent of legal consequences in compliance with general criminal laws, if an appeal was only filed to this person's benefit.

\section{Conclusion}

The prohibition of reformatio in peius is a requirement derived from several fundamental principles. Legal practice has shown that the defendant has an "accumulated disadvantageous position" during the criminal procedure. The prohibition of reformatio in peius therefore is favour for the defence. It is included in the effective Hungarian Criminal Procedure Code regarding the rules of ordinary and extraordinary legal remedies, separate procedures; in addition, it is even regulated by the law of minor offences.

According to KORINEK (1989), as for the constitutional procedure, this key-definition came into the limelight basically in the German legal literature. The ground of prohibition of reformatio in peius lies in the prohibition of double jeopardy and the command of equity. Nevertheless, the prohibition of reformatio in peius is not an inevitable consequence of the rule of law, only a legal favour.

The mostly proclaimed counter-argument against the prohibition of reformatio in peius is that in certain countries (some provinces of Switzerland, Great-Britain) this institution is unknown, but still there is no doubt about the constitutionality of these countries. Though, this cannot be a conclusive argument against the definition deriving from the principle of constitutionality. The reference to the legal order of other countries solely does not give grounds to refuse the constitutional basis for the prohibition of reformatio in peius, as a criminal procedural institution, thus the definition of constitutional principles cannot be determined by the mere comparison of legal institutions.

Furthermore, the prohibition of reformatio in peius is even restricted by several provisions which allow aggravation de lege lata even though the judgment was appealed only in favour of the defendant. In Hungary there are numerous possibilities granted by law to increase the severity of sentences no matter whether the prohibition of reformatio in peius prevails, since in the procedure of second instance several detrimental 
decisions can be taken for the lack of an appeal filed to the detriment of the accused (but e.g. in the course of extraordinary remedies, all kinds of increase is forbidden by law, if the extraordinary remedy was initiated in favour of the accused).

The prohibition of reformatio in peius, as a part of a fair procedure, can be considered as a requirement of the principle of constitutionality. But if we would like to make a conclusive decision whether the prohibition of reformatio in peius is an element of the principle of constitutionality, it should be rather stated that it is more precise to call the prohibition of reformatio in peius as a constitutional guarantee, since it still can raise many contradictions and arguments.

\section{References}

BALOGH Zsolt - HOLLÓ András - KUKORELLI István - SÁRI János: Kommentár a Magyar Köztársaság Alkotmányáról szóló (1949). évi XX. törvényhez. COMPLEX Jogtár, 2009. április 30. Commentary on section 2.

BAUMANN, LARS ANTON (1999). Das strafprozessuale Verbot der reformatio in peius und seine Besonderheiten im Jugendstrafrecht. Aachen, p. 21

BLECKMANN, Albert (1993). Staatsrecht I - Staatsorganisationsrecht. Grundlagen, Staatszielbestimmungen und Staatsorganisationsrecht des Bundes. Köln - Berlin - Bonn - München, pp. 392-585

BLOY, René (1986). Die Ausgestaltung der Rechtsmittel im deutschen Straf $\neg$ prozeß . Juristische Schulung, p. 589

BRUNNER, Rudolf (1972). Urteilsanmerkung. Juristische Rundschau, p. 74

BRUNS, Hans-Jürgen (1979). Der,,Bestimmtheitsgrad” der Punktstrafe im Strafzu $\neg$ messungsrecht. Neue Juristische Wochenschrift, p. 289.

DEGENHARDT, Christoph (1996). Staatsrecht I. Staatszielbestimmungen, Staatsorgane, Staatsfunktionen. Heidelberg, item 319.

EISENBERG, Ulrich (1997). Jugendgerichtsgesetz. Kommentar. München, item 73.

FENYVESI Csaba - HERKE Csongor - TREMMEL Flórián (2004). Új magyar büntetőeljárás. Dialóg-Campus Kiadó, Budapest-Pécs, pp. 36-65

FLAD, Herbert (1989). Das Verbot der reformatio in peius - eine vom Gesetz $\neg$ geber gewährte Rechtswohltat oder ein Gebot des Verfassungsrechts. In: Dogmatik und Praxis des Straf $\neg$ verfahrens - Beiträge anläßlich des Colloquiums zum 65. Geburtstag von Gerhard KIELWEIN. Köln - Berlin - Bonn - München, pp. 101-106

GRÜNWALD, Gerald (1979). Urteilsanmerkung. Juristische Rundschau, p. 300

KADEL, Berthold (1983). Die Bedeutung des Verschlechterungsverbots für Geldstrafenerkenntnisse nach dem Tagessatzsystem. Brühlscher Verlag, p. 7

KORINEK, László (1989). A nyugatnémet bünmegelözés története, felépitése és müködése. Belügyi Szemle, 10, pp. 110-117

KRETSCHMANN, Hans-Jochen (1968). Das Verbot der reformatio in peius im Jugendstrafrecht. Saarbrücken, p.6

LAUCKNER, Rolf (1913). Zur Geschichte und Dogmatik der reformatio in peius. Breslau, p. 54

MAUNZ, Theodor - DÜRIG, Günter - HERZOG, Roman - SCHOLZ, Rupert - LERCHE, Peter - PAPIER, Hans-Jürgen - RANDELZHOFER, Albrecht - SCHMIDT-ASSMANN, Eberhard (1990): Grundgesetz. Kommentar. Loseblattausgabe. München. Commentary on Article 20., Note No 201 on Artcile 3. III. and Note No 258 on Artcile 3. III.

MERTEN, Detlef (1975). Rechtsstaat und Gewaltmonopol. In: Recht und Staat, p. 12

MEYER-GOßNER, Lutz (1985). Einstellung des Verfahrens und Verschlechterungsver $\neg$ bot. In: GÖSSEL, Karl Heinz - KAUFMANN, Hans (ed.). Strafverfahren im Rechtsstaat. Festschrift für Theodor KLEINKNECHT. München, p. 287

MÜLLER (1647). Anmerkung zu OLG Tübingen. Strafsenat vom 14. 11. 1946 - Ss 9/46. Deutsche Rechtszeitschrift, p. 101

NIEMÖLLER, Martin - SCHUPPERT, Gunnar Folke (1982): Die Rechtsprechung des 
Bundesverfassungsgerichts zum Strafverfahrensrecht. Archiv des öffentlichen Rechts, p. 405

PETERS, Karl (1957). Anmerkung zu BGH, Urteil vom 18. 7. 1956 - 6 StR 28 / 56. Juristenzeitung, pp. 482-483

PFEIFFER, Gerd (ed.) (1993). Karlsruher Kommentar zur Strafprozeßordnung und zum Gerichtsverfassungsgesetz mit Einführungsge $\neg$ setz. München, item 170.

ROXIN, Claus (1998). Strafverfahrensrecht. München, Commentary on section 2.

SCHAFFSTEIN, Friedrich - BEULKE, Werner (1995). Jugendstrafrecht. Eine systematische Darstellung. Stuttgart - Berlin - Köln, Commentary on section 38.

SCHMIDT-AßMANN, Eberhard (1976). Verwaltungsverantwortung und Verwal $\neg$ tungsgerichtsbarkeit. Veröffentlichungen der Vereinigung der Deutschen Staatsrechtslehrer, Commentary on Article 19.

SCHÖNKE, Adolf - SCHRÖDER, Horst (1997). Strafgesetzbuch. Kommentar. München, Commentary on section 38 .

SCHROEDER. Friedrich-Christian (1997). Die Rechtsnatur des Grundsatzes, ne bis in idem”. Juristische Schulung, p.227

STERN, Klaus (1984). Das Staatsrecht der Bundesrepublik Deutschland. Bd. I. München, p. 772

STRENG, Franz (1991). Strafrechtliche Sanktionen: Grundfragen und Anwen $\neg$ dungen. Stuttgart - Berlin - Köln, p. 193.

TIEDEMANN, Klaus (1991). Verfassungsrecht und Strafrecht. Heidelberg, p. 69

TRÖNDLE, Herbert (1997). Strafgesetzbuch und Nebengesetze. Mün $\neg$ chen, Commentary on section 46.

VON MÜNCH, Ingo - KUNIG, Philip (ed.) (1992). Grundgesetzkommentar, Band 1. From Preamble to Art. 20 and Note No. 35 on Article 103.

\section{Legal regulations}

Decision No. 10/1992 (II. 25.) of the Constitutional Court (of Hungary)

Decision No. 11/1992 (III. 5.) of the Constitutional Court (of Hungary)

Decision No. 30/1992. (I. 26.) of the Constitutional Court (of Hungary)

Decision No. 9/1992 (I. 30.) of the Constitutional Court (of Hungary)

\section{Notes}

Note 1. According to the requirements of constitutional criminal law, the disposition - which holds out the prospect of penalty and determines the forbidden act - must be worded precisely, clearly and limited. The legislative will concerning the protected legal subject and the act of perpetration is expressed clearly by the constitutional requirement. It must contain unambigous message when does the act of the perpetrator constitute a criminal offence punished by criminal law. However, the legislator's arbtirary subjective interpretation of the law shall be restricted. Thus, we must be careful whether the statement of facts designates the acts to be punished too boadly and is explicit enough.-- pronounced by Decision No. 30/1992. (I. 26.) of the Constitutional Court 